International Journal of Electronics and Communication Engineering and Technology (IJECET)

Volume 10, Issue 2, March-April 2019, pp. 17-22. Article ID: IJECET_10_02_003

Available online at

http://iaeme.com/Home/issue/IJECET? Volume $=10 \&$ Issue $=2$

ISSN Print: 0976-6464 and ISSN Online: 0976-6472

(C) IAEME Publication

\title{
DESIGN AND IMPLEMENTATION OF SMART HOME CONTROL USING NI LAB VIEW
}

\author{
Vasantha Sasikala, Surakasula Cherishma and Tiyyagura Prasanna Reddy \\ Department of Electronics and Communication Engineering, \\ K L University, Vaddeswaram, Andhra Pradesh, India
}

\begin{abstract}
ABTRACT
Now a days we are searching for security everywhere especially in our home and we want to operate everything automatically according to surroundings, situations particularly when it comes to home, we prefer more security and work has to complete automatically. For example, when we enter into room lights and fans has to operate based on our movements and humidity, and external lights of the home has to operate based on sunlight and lock system gets unlocked whenever the owner enters a key set by him correctly otherwise an alarm will be rang so that owner knows someone has tried to open the door. In water tank system, when the water level of the tank is less than minimum value, motor will on and if the water level of the tank reaches the maximum value motor will be off automatically. In this paper, we are going to observe all these features to convert normal home to smart home by using sensors and controllers.
\end{abstract}

Keywords: LabView, Temperature Sensors, Automation, Alarm, LED's.

Cite this Article: Vasantha Sasikala, Surakasula Cherishma and Tiyyagura Prasanna Reddy, Design and Implementation of Smart Home Control using NI Lab View, International Journal of Electronics and Communication Engineering and Technology, 10(2), 2019, pp. 17-22.

http://iaeme.com/Home/issue/IJECET?Volume=10\&Issue=2

\section{INTRODUCTION}

In olden days, we are using all traditional methods like lock with a key for security for main door to avoid thiefs and strangers entering the home without our permission [1].In past days we used to operate manually the electrical switches but now a days everyone is expecting to do those minor things automatically so that we can save electricity[2]. We often see

overflowing of water to avoid this we are using Water tank monitoring system. In this paper, we observe all these implementations and controlling of the systems using Lab View. For example, all cases have to run simultaneously or parallel so using Lab View software we achieve it. Smart home can also provide the wireless communication through remotes or mobile phones. Using mobile phones, we can operate TV's, Air Conditioners, Fans, Lights, motors and also projectors. 
In smart home technology, we are going to use five types of systems 1. Room Temperature Controlling System 2.Water Tank Monitoring System 3.Anti-theft Alarm System[3] 4.Garden Watering System. These are all implemented using NI-Lab View [4].

\subsection{NI Labview}

NI Lab View is a software which is widely used for application development in industries. In this we observe both software and hardware. It has a GUI (Graphical User Interface) feature. Due to this feature, user interaction is most friendly in this software. In Lab View, we have two panels: front panel and block diagram. Front panel is used for displaying inputs and outputs and in block diagram we are going to design the code for the application. In front panel, we have features like picture insertion, font changing, colour changing of LED's and decoration items like Raised Frame, Raised Circle, Flat Frame, Flat Circle, Flat Box etc.,. When we right click on the front panel we get the controllers like Numeric, Boolean, String and Path, Array, Matrix and Cluster, Ring and Enum, Graph etc.,. In block diagram, we observe Structures (for loop, while loop, Case structure, Event structure, Flat sequence), Array (Array operations), Cluster (Cluster operations), Numeric (Add, Subtract, Multiply etc.,), Timing (Wait, Tick count etc.,), Waveforms (ADC, DAC etc.,). All these features together make NI Lab View as a leading software for application development.

\section{DESIGN AND IMPLEMENTATION}

\subsection{Room Temperature Monitoring System}

In this Room Temperature Monitoring System in Figure 1, we observe a sensor, thermometer, reference temperature. Sensor compares the room temperature with critical temperature which is known as reference temperature. If room temperature is less than or equal to critical temperature it switches on the heater as shown in Figure 2. If room temperature is more than critical temperature it switches on the air conditioner. For example, if a person is ill and confined to bed, this system is very useful for monitoring room temperature without human intervention.

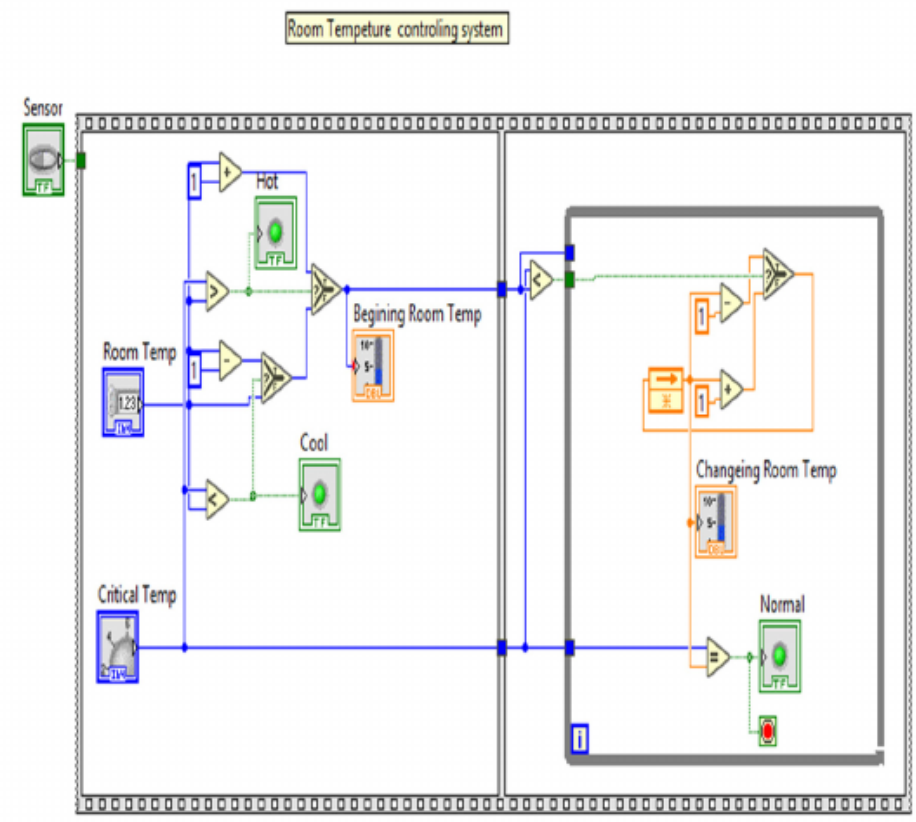

Figure 1 Block diagram of Room Temperature Monitoring System 


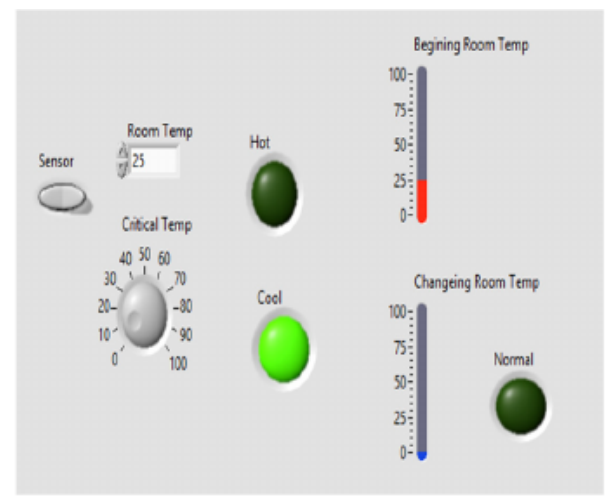

Figure 2 Front Panel of Room Temperature Monitoring System

\subsection{Water Tank Monitoring System}

In this Water Tank Monitoring System shown in Figure 3, we observe tank, alarms and water level indicators. Here we observe the minimum and maximum water level indicators. If water level of the tank reaches minimum value then motor will be turned ON automatically as shown in Figure 4. If water level of the tank is reaches maximum value then motor will be turned OFF automatically as shown in Figure 5. If it reaches the minimum level or maximum level we get an alarm to alert us. Often we forget to switch off the motor which leads to overflow of water thereby wasting lot of water and sometimes we forget to switch on the motor which leads to shortage of water in emergency times. To avoid this situations, it is advised to use Water Tank Monitoring System in everyone house. ( ${ }^{\circledR}$

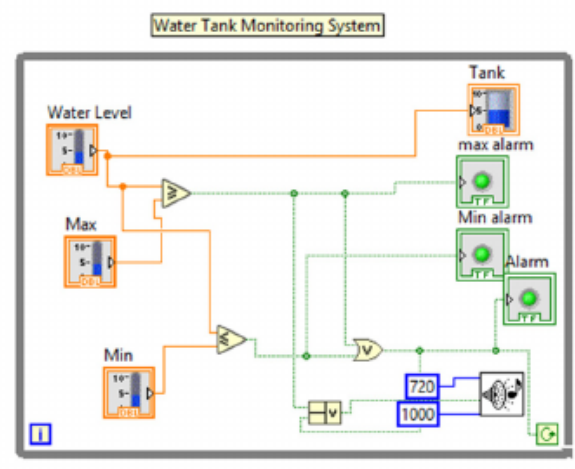

Figure 3 Block diagram of Water Tank Monitoring System

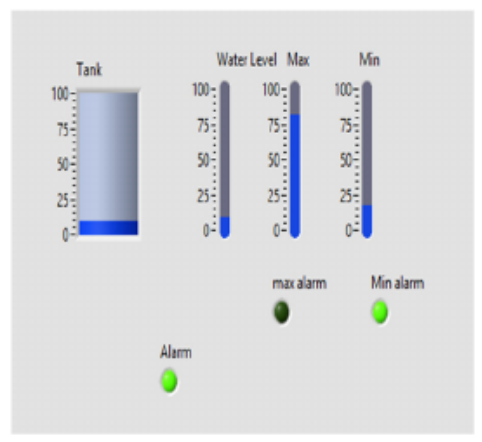

Figure 4 Front Panel of Water Tank Monitoring System with minimum level 


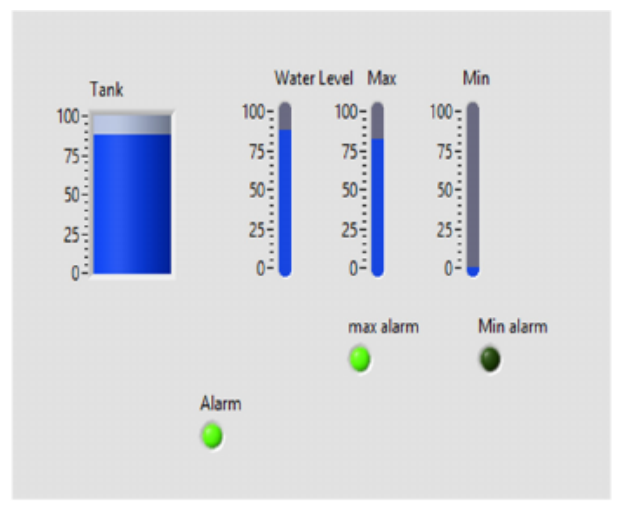

Figure 5 Front Panel of Water Tank Monitoring System with maximum level

\subsection{Anti-Theft Alarm System}

In this Anti-theft Alarm System shown in Figure 6, we use digital locker and a alarm. Here we observe the keypad to enter user's password to unlock the door. If user's password is matched with the predefined password, then door will be opened as shown in Figure 7. If user's password is not matched with the predefined password, then an alarm will be rang to alert the owner or neighbours that someone is trying to open the door. Robberies are increasing day by day so it preferable to have a security locking system.

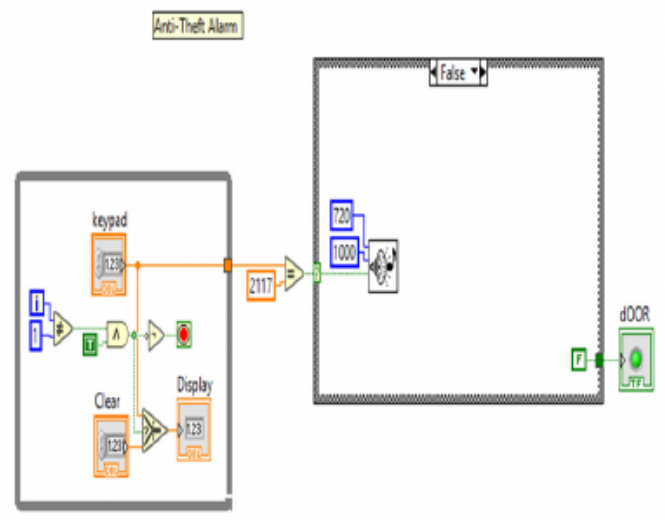

Figure 6 Block diagram of Anti-Theft Alarm System

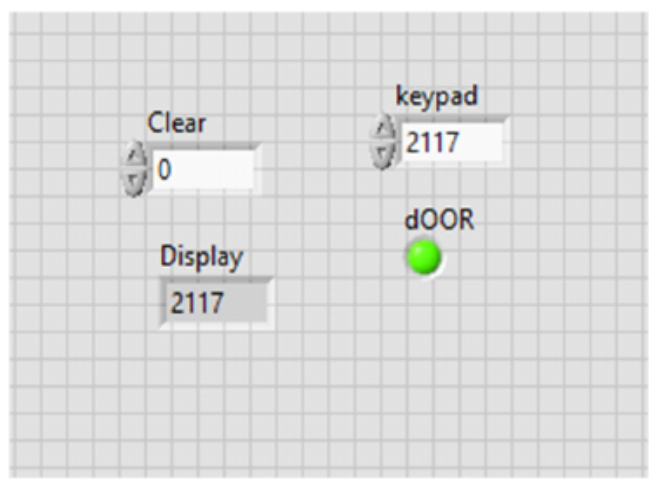

Figure 7 Front Panel of Anti-Theft Alarm System 


\subsection{Garden Watering System}

In this Garden Watering System shown in Figure 8, we set timings in morning and evening. At that particular timing only water will be sprinkled in garden for a particular time interval. All this is done by using Time Stamp in Lab View. Here we are going to set the start and stop timing in Time Stamp based on that sprinklers will be ON or OFF as shown in Figure 9. It is better to have a garden in everyone home but due to busy schedule they are unable to water them regularly so no one is preferring to have a garden. This Garden Watering System helps us to have a good garden without our involvement.

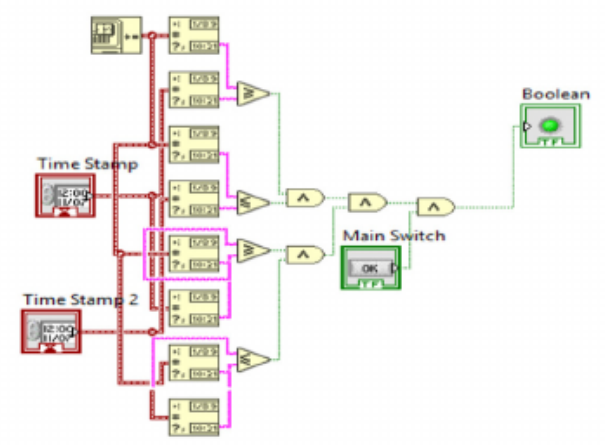

Figure 8 Block diagram of Garden Watering System

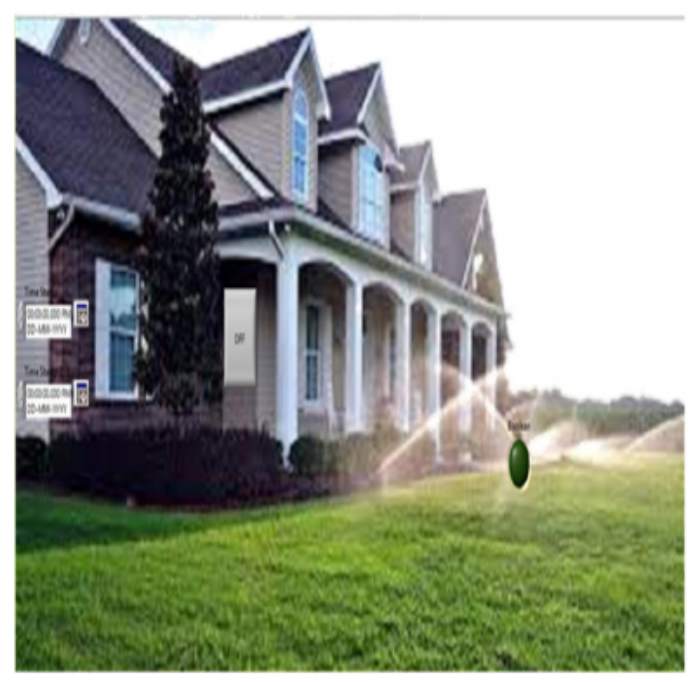

Figure 9 Front Panel of Garden Watering System

\section{CONCLUSIONS}

Smart home automation is therefore displayed and simulated utilizing LabVIEW. We have built up an adaptable particular keen home application utilizing the visual programming worldview and the LabVIEW condition, which meets effectively the underlying client prerequisites for a totally utilitarian system. LabVIEW is perfect for any estimation or control system, incorporating graphical devices that encourage the working of an extensive variety of utilizations in drastically less time than utilizing different practices. Obviously, the displayed system displaying and execution worldview can be effectively relocated to an expansive scope of computerization applications. 


\section{FUTURE SCOPE}

Now a days People are searching for easy process in doing work for our home also should become automatic like glowing lights automatically and temperature control, Door opening etc. These all in are automatic system. This project may helps people to do thing automatically. The next phase for the Home automation market will occur based on a few key improvements in the technology available in Automation, such as improvement in Wireless Automation solutions as well as lowering of price points as the market begins to accept Home automation usage in larger volumes. Big companies like Philips, Siemens \& Schneider will eventually bring out fairly mass-market automation products with appealing user interface but at a lower price point than today, and more people will be able to afford the products. Solution offerings will slowly move to a more user-friendly design, where aside from a few key components, users will be able to buy and use the Automation products themselves without the aid of any technical expert.

\section{REFERENCES}

[1] Basil Hamed, "Design \& Implementation of Smart House Control Using LabVIEW", International Journal of Soft Computing and Engineering (IJSCE), Volume 1, Issue 6, January 2012. Hamed.

[2] Peeyush Garg, Sankalp Agrawal, "Amit Saraswat, "Design and Implementation of Interactive Home Automation System Using LabVIEW", Proceedings of First International Conference on Smart System, Innovations and Computing, pp.371-381, January 2018.

[3] Kour G., J.: Lab VIEW Based Alarm Systems in Home: In: UNIASCIT, Vol 2, Issue-3, pp. 305-307 (2012).

[4] Anil Aravind, R Thampi Prathap, John M and Shanthi K J, "An Automated Irrigations systems for Home Gardens" India conference (INDICON), Annual IEEE, 2012.

[5] A.R. AI-Ali, Murad Qasaimeh, Mamoun AI-Mardinia, Suresh Radder and I. A. Zualkernan" ZigBee-Based Irrigation System for Home Gardens" Communications, Signal Processing, and their Applications (ICCSPA), International Conference, 2015.

[6] Armin Barghi and Amir Reza Kosari, Maede Shokri and Samad Sheikhaei, "Intelligent Lighting Control with LEDs for Smart Home" Smart Grid Conference (SGC), 2014.

[7] Becker, B.; Kellerer, A.; Schmeck, H, "User Interaction Interface for Energy Management in Smart Homes" Innovative Smart Grid Technologies (ISGT), IEEE PES, 2012. 